\title{
Hydro-morphologic setting of the Samborombón Bay (Argentina) at the end of the 21 st century
}

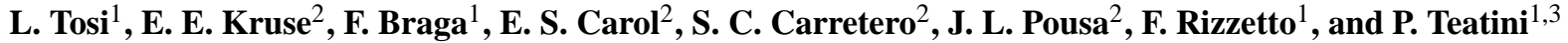 \\ ${ }^{1}$ Institute of Marine Sciences, National Research Council, Arsenale, Tesa 104, Castello 2737/F, 30122, Venice, Italy \\ ${ }^{2}$ Consejo Nacional de Investigaciones Científicas y Técnicas. Facultad de Ciencias Naturales y Museo, \\ Universidad Nacional de La Plata, 64 \#3, 1900, La Plata, Argentina \\ ${ }^{3}$ Department of Civil, Environmental and Architectural Engineering, University of Padova, Via Trieste 63, 35121, Padua, Italy
}

Correspondence to: L. Tosi (luigi.tosi@ismar.cnr.it)

Received: 25 July 2012 - Published in Nat. Hazards Earth Syst. Sci. Discuss.: -

Revised: 12 December 2012 - Accepted: 7 January 2013 - Published: 4 March 2013

\begin{abstract}
We report on the hydrologic and morphologic setting of the Samborombón Bay, Argentina, which is expected at the end of the 21 st century as a consequence of possible scenarios of relative sea level rise (RSLR). The geomorphological analysis of the Samborombón coastland points out only minor changes occurred over the last $40 \mathrm{yr}$. The modifications are mainly related to the construction of canals to enhance the floodplain drainage. A digital elevation model (DEM) obtained by the Shuttle Radar Topography Mission (SRTM) data archive, ad hoc calibrated/validated for the study area, highlights that about $3000 \mathrm{~km}^{2}$ of coastal plain present a morphological setting at high risk of sea flooding. The analysis of sea level and storm surge events recorded from 1905 to 2010 in Buenos Aires provides the RSLR rate and the return period of extreme floods. In addition, vertical land movements (VLM) measured by the permanent GPS stations of Buenos Aires and La Plata allow for the quantification of the eustatic component of the RSLR and estimating a plausible RSLR rate in the Samborombón Bay. Taking into account possible RSLR scenarios at the end of 2100 as resulting from the statistical analysis of (i) tide gauge and GPS time series and (ii) Intergovernmental Panel on Climate Change (IPCC) predictions, the potential effect of the increased sea level on the Samborombón coastland is simulated. The results show that the combined rise of sea levels, surficial waters and groundwater will lead to a new morphohydrologic setting of the coastal area, especially in the lowlying southern sector. Here, a coastline retreat up to $40 \mathrm{~km}$ is expected, with temporary submersion up to $4000 \mathrm{~km}^{2}$ during storm surges.
\end{abstract}

\section{Introduction}

The hydro-geomorphologic setting of coastal areas is the result of complex interactions between marine and continental processes. The majority of human settlements and industrial zones are located in coastal areas where human pressure on the environment is constantly growing. Lowland morphologies make coastlands the areas at the highest risk of flooding, land subsidence, and saltwater contamination of groundwater resources (e.g. IPCC, 2007; Pousa et al., 2007; Syvitski et al., 2009; Teatini et al., 2011; Strauss et al., 2012). The significant increase of sea level rise (SLR), as expected in the present century according to several studies (e.g. Nicholls and Cazenave, 2010), is probably the most relevant problem jeopardizing coastal plains. Long-term SLR is difficult to determine because this process involves the interaction of several components of the climate and earth systems. Nicholls and Cazenave (2010) summarized the average evolution of mean sea level between 1800 and 2100 from observations and model projections and pointed out that the SLR projection in 2100 would range between 0.2 to $1.2 \mathrm{~m}$ with respect to the present level. Of course, this rise would not be uniform, as it is indicated by all general circulation models coupling atmospheric and ocean circulations (IPCC, 2007).

The Samborombón Bay, Province of Buenos Aires, Argentina, can be considered a relevant case study to understand the effect of relative SLR (RSLR), i.e., the combination of eustatic rise and vertical land movement (VLM), on coastal plains. Specific information on the RSLR in the surroundings are obtained by processing the tide gauge 


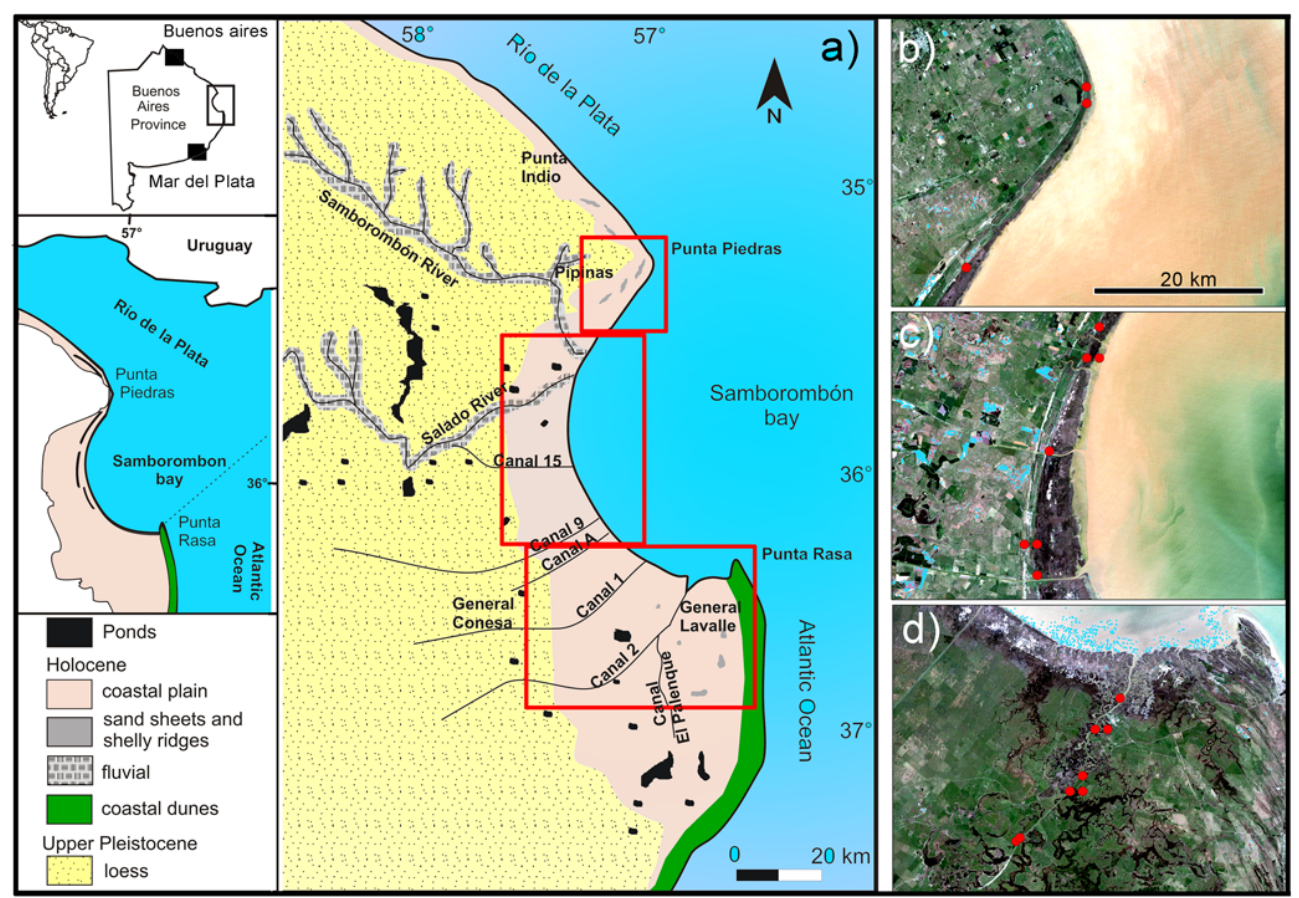

Fig. 1. (a) Simplified geological-geomorphological map of the Samborombón coastland. Landsat images of the (b) northern, (c) central, and (d) southern sectors of the study area. The location of the groundwater and surficial-water monitoring stations are represented by red dots.

data recorded at Buenos Aires and Mar del Plata, $200 \mathrm{~km}$ to the north and south, respectively. Linear regression of mean annual values indicates a long-term RSLR equal to $1.68 \pm 0.05 \mathrm{~mm} \mathrm{yr}^{-1}$ at Buenos Aires for the period 19052003 (D'Onofrio et al., 2008) and $1.60 \pm 0.10 \mathrm{~mm} \mathrm{yr}^{-1}$ at Mar del Plata between 1956 and 2005 (Fiore et al., 2009). Notice that Buenos Aires is located on the Rio de la Plata estuary shore and Mar del Plata on the open South Atlantic Ocean. Using a least squares regression fit according to a simple quadratic parameterization, D'Onofrio et al. (2008) and Fiore et al. (2009) calculated an RSLR acceleration of $0.019 \pm 0.005 \mathrm{~mm} \mathrm{yr}^{-12}$ at Buenos Aires and $0.120 \pm 0.006 \mathrm{~mm} \mathrm{yr}^{-12}$ at Mar del Plata for the two periods.

The Samborombón Bay stretches along $180 \mathrm{~km}$ of coastline on the outer estuary of the Rio de la Plata (Fig. 1) and consists of salt marshes and marshlands, whose width varies from $100 \mathrm{~m}$ to $15 \mathrm{~km}$ in the northern and southern sectors, respectively. The Samborombón Bay wetlands are a Ramsar natural reserve subjected to periodic floods due to rainfall, runoff, tidal fluctuations, and storm surges. The marshlands are extremely productive, exhibit high biodiversity, and are favorable for livestock development.

The coastal plain is composed of Pleistocene-Holocene deposits showing the signs of the sea level fluctuations that occurred over this period (e.g. Violante et al., 2001; Cavallotto et al., 2004; Violante and Parker, 2004; Fucks et al., 2010) and displays an estuary characterized by microtidal regime where marine water penetrates below the fresh water of the Rio de la Plata (e.g. Acha et al., 2008). The Pleistocene sedimentation is mainly characterized by loess deposits and shell ridges, both outcropping west of the coastal plain (Fig. 1), whereas lacustrine and fluvial facies occur in depressed areas and ancient distributary channels, respectively. The Holocene sequence is represented by littoral barrier environments that migrated across the shelf during the transgression. Outcrops of shell ridge deposits, up to $10 \mathrm{~km} \mathrm{long,}$ from 50 to $120 \mathrm{~m}$ wide, and elevated from 4 to $7.5 \mathrm{~m}$ above mean sea level (m.s.l.), are located parallel to the coastline (Fig. 1). Fluvial deposits are restricted to the proximity of the minor rivers flowing into the bay. The coastal plain widens southward and in the salt marsh area the density of natural channels increases. Here, shell ridges gradually thin and pass to small isolated outcrops of aeolian sandy layers.

From the hydrologic point of view, the bay forms the eastern boundary of the depressed area of the Salado River (Fig. 1). The region is characterized by a very mild slope and by extremely low morphogenetic potential and piezometric gradient that make runoff difficult. In order to mitigate the effect of frequent prolonged flooding occurring in wet periods, a regional drainage network formed by seven major and more than twenty smaller canals has been constructed.

Carol et al. $(2008,2009,2010)$ studied the hydrogeology of the Samborombón Bay. They found that the water budget is mainly associated with rainfall, runoff, and groundwater flow, but wetlands located near coastal zones may also have a certain amount of seawater inflow through tidal influence. Water dynamics is determined by soil properties and geological/geomorphological characteristics of the wetland. 
Soils and groundwater of the Samborombón coastal plain are highly salinized. Freshwater reserves are scarce, with lenticular volumes contained within shell ridges and thin sandy layers. Their availability is strictly connected to the amount of local rainfalls, which is the only recharge. The drainage of excessive water volumes through the system of canals, groundwater mismanagement and exploitations, shell ridge quarry (mining activities), and disposals of sewage severely compromise the freshwater reserves, as well as the wetland ecosystem.

Several authors pointed out that the Samborombón Bay is an area characterized by a potentially high risk of flooding in view of the expected climate changes. D'Onofrio et al. (1999) estimated the return periods of extreme water levels for some vulnerable areas of Buenos Aires and found that a $3.30 \mathrm{~m}$ flooding level due to tide and storm surge is characterized by a $5 \mathrm{yr}$ return period only. Based on the various physical characteristics of the coastal sectors (e.g. elevation, geology, geomorphology, shoreline erosion/accretion, average wave height, mean tidal range, and RSLR due to eustasy and local tectonics), Diez et al. (2007) verified that equation CVI6 by Gornitz et al. (1997) is appropriate for the analysis of coasts with different morphologies and characterize the stretches of the coastland in the Buenos Aires province that present different degrees of risk in view of the expected RSLR. Lamaro et al. (2009) detected morphologic changes that occurred in the Samborombón Bay over the last 40 to $70 \mathrm{yr}$ by integrating topographic maps and satellite images. They identified an extensive progradation in the central and southern portions (Punta Rasa, Fig. 1) of the bay. The mean land progradation from 1968 to 2005 amounted to $600 \mathrm{~m}$ along the central coast and the average distance between the 1938-1941 and 2005 shorelines reached $456 \mathrm{~m}$ in Punta Rasa. On the contrary, a slight coastline regression was observed in the northern sector (Punta Piedras, Fig. 1). However, the authors did not take into account daily fluctuations of the tide that, in intertidal zones characterized by low topographic slopes, may produce significant apparent changes of the morphologic setting. Conzonno et al. (2001) analyzed the impact of man-made surficial drainage network on the lower catchment of the Salado River and found that, because of the canal construction, the reduced water discharge from the Salado River caused a change in the ecological and hydrological settings and, consequently, in the socioeconomic conditions of the local population.

The objective of our study is the quantification of the effects of potential RSLR scenarios on coastal morphology and surficial water-groundwater interaction in the Samborombón coastland. After a brief characterization of the hydro-geomorphologic setting and updated oceanographic and meteorological conditions, we estimate the sea flooding extent and the groundwater level changes that are expected at the end of the 21 st century as a consequence of plausible scenarios of RSLR.

\section{Materials and methods}

This study combines satellite image interpretation with geological, geomorphological, hydrological, and hydrogeological surveys.

The assessment of long-term morphological changes over a specific time interval needs a homogenous data series, such as frequent images with an adequate spatial resolution. However, for a wide area like the Samborombón coastland, the possibility of using good data-series with optimal resolution is difficult (or expensive). Integrated multi-scale and multiresource data analyses are the appropriate methods for overcoming this problem. Satellite images acquired from 1972 to 2011 in similar tide condition are used to map the coastal plain and detect the morphological changes at two scales of investigation: at regional level, covering the entire bay area, and at local level, corresponding to the three sectors (northern, central, and southern) of the coastland. These zones are characterized by unlike features and will likely respond in different ways to climate and man-induced changes.

Landsat MSS, Landsat 5 TM, and Landsat 7 ETM+ satellite images (path 224, row 85) with spatial resolutions ranging from 15 to $60 \mathrm{~m}$ were obtained from the Earth Resources Observation and Science (EROS) Center of the US Geological Survey (Table 1). The images are characterized by cloud-free or low cloud cover sky conditions over the whole test site. All Landsat bands have been used for the analysis, except the thermal band. Each image has been radiometrically corrected with the values of gain and offset reported in metadata file and geometrically corrected using ITT Visualization System's ENVI image processing software. RGB band composition has been made for the visual interpretation of regional evolution. In order to assess the main geomorphological changes, the water levels (i.e., the calculated astronomical level) synchronous with satellite acquisitions have been taken into account and calculated by the $\mathrm{Wx}$ tide v.4.7 software (http://www.wxtide32.com). Among the USGS database, a few Landsat images were selected to highlight the effects of extreme conditions, such as river flooding and storm surge, on the coastal zone and surrounding areas. These effects are likely to get worse due to climate changes.

Surficial water and groundwater monitoring networks were established in each area with measurements starting in 2008. Measuring sites are located in the channels and series of 3-m-deep wells were drilled along alignments orthogonal to the coastline and crossing the shell ridges (Fig. 1). Lithostratigraphic investigations were performed to define the hydrogeological units. Chemical analyses on surficial water and groundwater samples were performed following Eaton et al. (1998).

Tide gauge records from the Buenos Aires and Mar del Plata stations (Fig. 1) are used to assess the long-term RSLR. Available measurements collected using hourly sampling rates and spanning the time intervals from 1905 to 2010 and from 1956 to 2010 , respectively, were statistically analyzed. 
Table 1. Satellite images used in the study to investigate the geomorphological evolution of Samborombón Bay and the flooding of the coastland.

\begin{tabular}{lllcl}
\hline $\begin{array}{l}\text { Acquisition date } \\
\text { (dd.mm.yyyy) }\end{array}$ & $\begin{array}{l}\text { Acquisition time } \\
\text { (hh:mm GMT) }\end{array}$ & Sensor & $\begin{array}{c}\text { Spatial } \\
\text { resolution (m) }\end{array}$ & Topic \\
\hline 20.10 .1972 & $13: 06$ & Landsat 1 MSS & 60 & Geomorphology \\
23.05 .1975 & $12: 54$ & Landsat 2 MSS & 60 & Geomorphology \\
20.09 .1976 & $12: 45$ & Landsat 2 MSS & 60 & Geomorphology \\
13.01 .1986 & $13: 13$ & Landsat 5 TM & 30 & Rio Salado flooding \\
25.06 .1987 & $13: 03$ & Landsat 5 TM & 30 & Geomorphology \\
13.09 .1987 & $13: 05$ & Landsat 5 TM & 30 & Geomorphology \\
07.10 .1996 & $12: 57$ & Landsat 5 TM & 30 & Geomorphology \\
30.11 .1998 & 13.17 & Landsat 5 TM & 30 & Geomorphology \\
04.06 .2000 & $13: 30$ & Landsat 7 ETM+ & $15 / 30$ & Rio Samborombón flooding \\
11.09 .2001 & $13: 27$ & Landsat 7 ETM+ & $15 / 30$ & Rio Samborombón flooding \\
12.08 .2007 & $13: 26$ & Landsat 5 TM & 30 & Geomorphology \\
09.09 .2009 & $13: 28$ & Landsat 5 TM & 30 & Coastal flooding \\
25.09 .2009 & $13: 28$ & Landsat 5 TM & 30 & Geomorphology \\
01.10 .2011 & $13: 26$ & Landsat 5 TM & 30 & Geomorphology \\
\hline
\end{tabular}

A digital elevation model (DEM) from Shuttle Radar Topography Mission (SRTM) (USGS/NASA), in particular the SRTM v.4 (Reuter et al., 2007; Jarvis et al., 2008), is used to simulate the expected sea encroachment in the next decades. SRTM data of the coastland sector between Punta Piedras and Punta Rasa are affected by errors, e.g. abrupt unphysical step-like morphology along straight alignments, probably due to the merge of acquisitions from different orbits. The SRTM DEM was improved as follows. First, the coastland was split along the step-like alignments into "consistent" portions. Then, the elevation dataset for each portion was shifted vertically to remove, or at least reduce as much as possible, the differences of level observed through the bounds. Finally, the adjusted SRTM DEM was calibrated by in situ data. To this aim, the topographic maps of the Argentina National Geographic Institute were geo-referenced, digitized, and finally used as reference by minimizing the difference between the topographic and satellite-based elevations.

\section{Hydro-geomorphologic setting}

Changes in geology and geomorphological features along the bay and the tidal influence from the estuary yield the existence of different hydrological environments with peculiar hydrodynamic and hydrochemical characteristics.

\subsection{Northern sector}

The northern sector of the Samborombón coastland is characterized by the highest topographic elevation, with Punta Piedras picking $13 \mathrm{~m}$ a.s.l., and a relatively narrow (approximately 100-200 m) marshland. From the hydrologic point of view, water courses are absent and only small tidal channels cross the marshland. The predominant deposits are shell ridges that host freshwater lenses recharged by precipitation. The Na- $\mathrm{HCO}_{3}$-type groundwater in the lenses flows toward the surrounding coastal plain and is characterized by low salt content averaging $0.5 \mathrm{~g} \mathrm{~L}^{-1}$. The marshland is periodically flooded by high waters and groundwater is less than $2 \mathrm{~g} \mathrm{~L}^{-1}$. Fluctuations of the groundwater level are connected with the tidal oscillation in the estuary.

Regional investigations carried out by comparing the satellite images acquired on 19 November 1975, and 20 November 2006 , under the same tidal conditions, reveal that no significant geomorphological modifications occurred in the marshland along the coastline over the last three decades (Fig. 2a-b). Conversely, the areas characterized by shell ridges have experienced strong hydro-geomorphologic modifications caused by the quarrying of the shell layers. These excavations are deeper than the phreatic level, producing depressed ponds where water table is exposed (Fig. 2c-e).

\subsection{Central sector}

The central sector of the Samborombón coastland is a depressed area crossed by the Samborombón and Salado Rivers, two major man-made watercourses, i.e., the Ancillary canal of the Salado River and the Canal 15, plus a number of other small ditches (Fig. 1). The Salado and Samborombón Rivers show active and inactive meandering shapes. The latter are usually flooded together with the most depressed portions of the plain (Fig. 3) during wet periods. The construction of the Canal 15 and the Ancillary Canal at the beginning of the 20th century and in 1987, respectively, has improved the drainage of the coastal plain. The salt marshes, which form an almost continuous strip 2-5 km wide, are completely flooded during high tides. In such conditions, estuary waters significantly encroach rivers and canals. Surficial waters and groundwater flow seaward from the mainland in low tide 


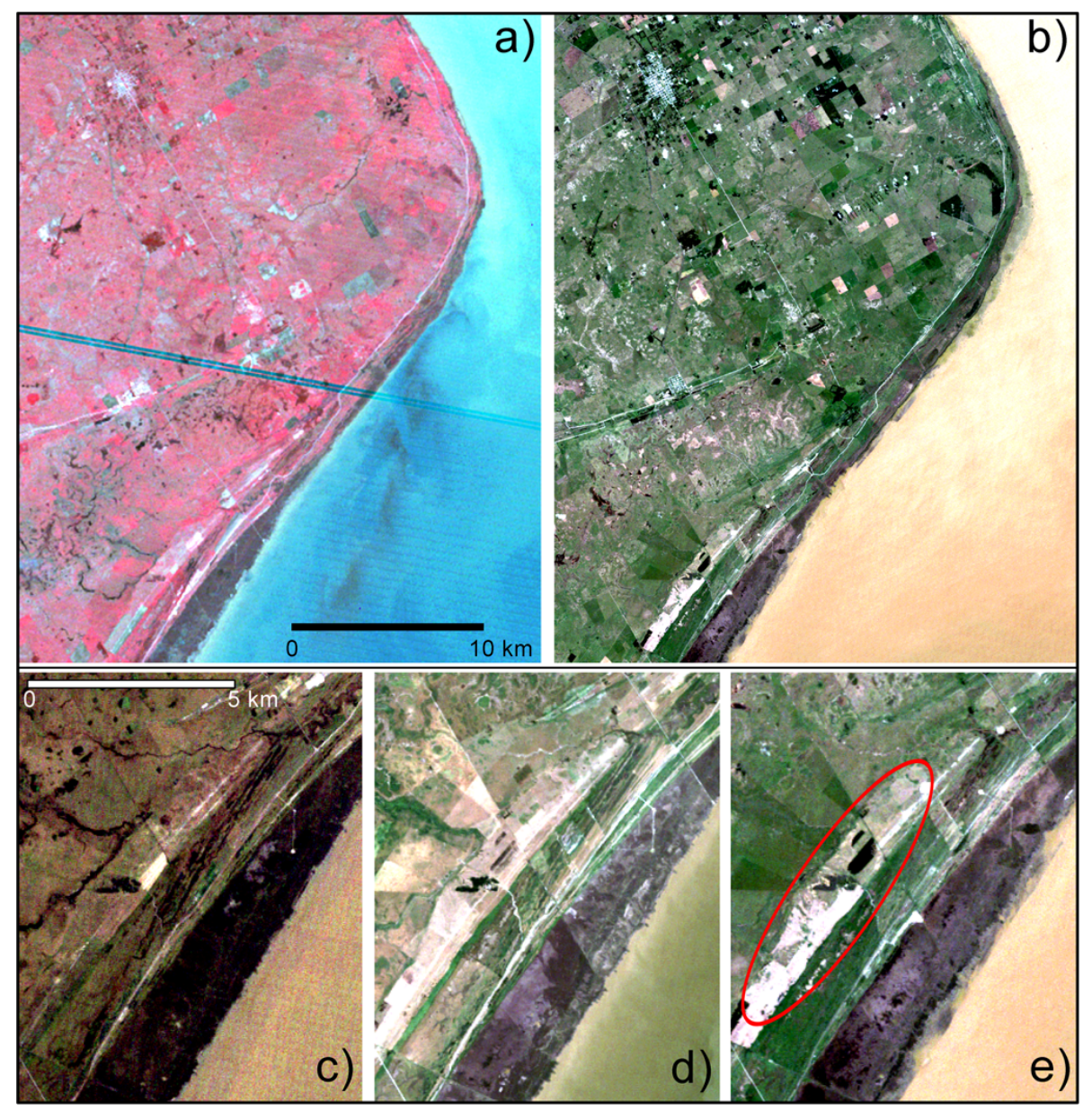

Fig. 2. Landsat images of the northern sector of the Samborombón coast acquired on (a) 20 September 1976 and (b) 1 October 2011 . An example of the hydro-geomorphologic modifications caused by the quarrying of shell layers can be detected by comparing the details dated (c) 25 June 1987, (d) 30 November 1998, and (e) 1 October 2011.

regimes. Because of the significant mixing between continental and marine waters, groundwater shows chemical properties similar to the estuarine water, i.e., an $\mathrm{Na}-\mathrm{Cl}$ salt content ranging from 8 and $15 \mathrm{~g} \mathrm{~L}^{-1}$. Similarly to the northern sector, fresh groundwater lenses (salinity below $0.5 \mathrm{~g} \mathrm{~L}^{-1}$ ) are contained into the shell ridges and sometimes are exposed because of several quarries (Fig. 4).

Along the proximity of the coastline, significant geomorphological changes have been triggered by the improving of the drainage network implemented during the last century. Most of the changes recognized in the nearby of the Rio Salado and Ancillary Canal mouths are the result of the artificial canal works (Fig. 4). The sequence of satellite images provided in Fig. 4 shows a general enlargement of the salt marshes and the tidal flats activated by the increased sediment discharge into the bay. The progradation mechanism is likely originated by the formation of a separate narrow strip of salt marshes which gradually merges to the older marsh margins. The salt marsh progradation, which is estimated up to $500 \mathrm{~m}$ between 1987 and 2011, is still active.

\subsection{Southern sector}

The southern coastal plain is characterized by $15-\mathrm{km}$ wide salt marshes crossed by several tidal channels and affected by tidal influence. The marsh area is crossed by the Ajó River, which is a watercourse formed by the confluence of the El Palenque Canal and the Canal 2 (Fig. 1). These canals have different chemical properties related with the drained catchment. The El Palenque Canal flows through the southern coastal plain and shows small $\mathrm{Na}-\mathrm{Cl}$ salt concentration, ranging between 1.3 and $1.5 \mathrm{~g} \mathrm{~L}^{-1}$. Conversely, the water of the Canal 2, which comes from a wider region located to the SW (Fig. 1), is fresh with salt content from 0.5 to $1.2 \mathrm{~g} \mathrm{~L}^{-1}$.

Along the intertidal area, hydrodynamics and hydrochemistry of groundwater strictly depend on the tidal regime, with $\mathrm{Na}-\mathrm{Cl}$ salinity usually greater than $10 \mathrm{~g} \mathrm{~L}^{-1}$. Thin sandy layers, less than $3 \mathrm{~m}$ high a.s.l., are located above the clayey deposits of the coastal plain. These highly permeable layers contain water with salinity concentration between 0.9 and 

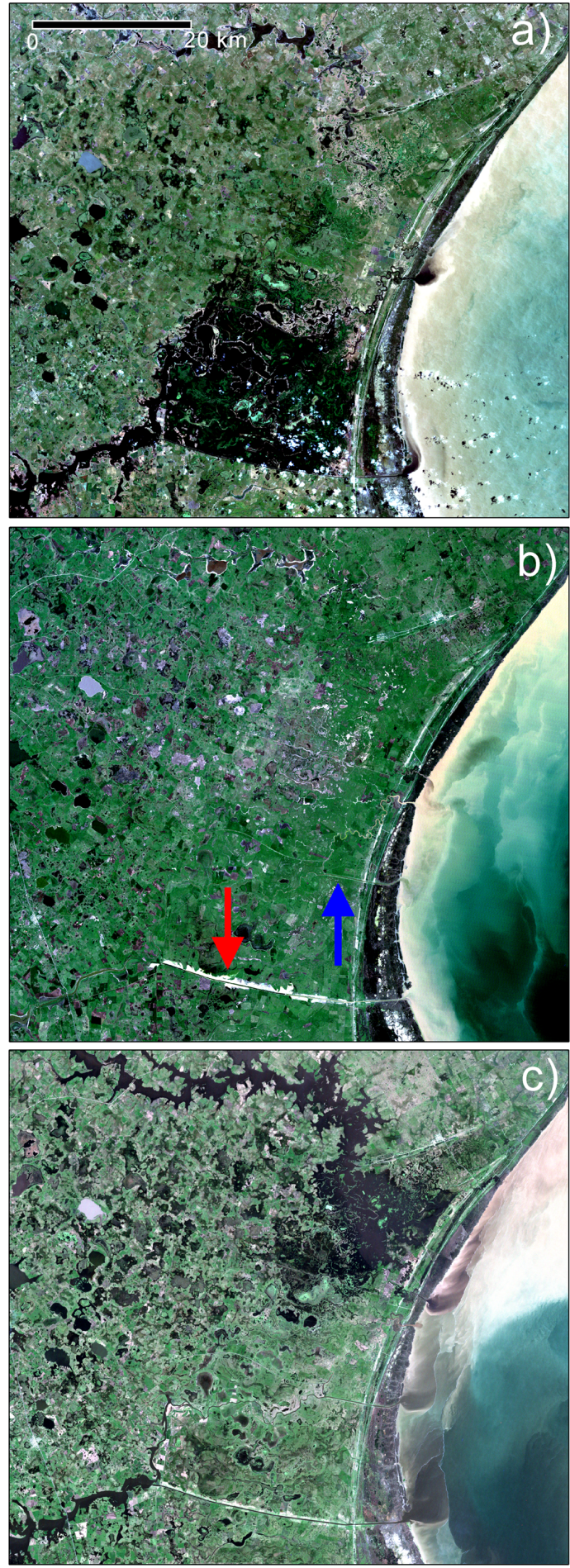

Fig. 3. Landsat images of the central sector of the Samborombón coastland acquired on (a) 13 January 1986, (b) 7 October 1996, and (c) 11 September 2001. (a) highlights the occurrence of a severe flooding of the Rio Salado; in (b) the dredging of the Canal 15 and the new Ancillary Canal are evidenced by the red and blue arrows, respectively; (c) shows a flooding caused by the Rio Samborombón.

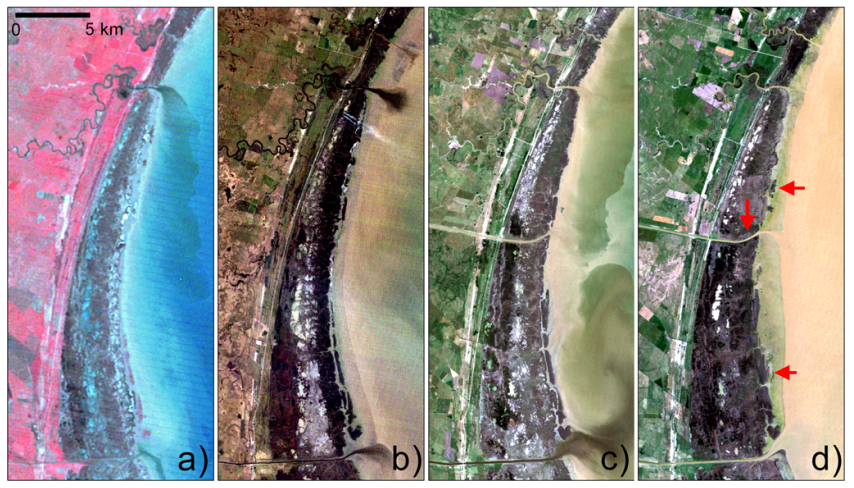

Fig. 4. Landsat images of the central sector of the Samborombón coast dated (a) 20 September 1976, (b) 25 June 1987, (c) 30 November 1998, and (d) 1 October 2011. The red arrows in (d) highlight the zones where the progradation of the salt marsh areas are more significant.

$3.2 \mathrm{~g} \mathrm{~L}^{-1}$, significantly lower than the groundwater of the intertidal area, and are recharged by precipitations.

Regional geomorphological changes occurred from 1975 to 2006 are not remarkable (Fig. 5a and b). In the wetland, the tidal creek network maintained its dimension and planform. Only a small regression of the coastline (few tens of meters wide) was observed along the southern bay margin, from $10 \mathrm{~km}$ west of the River Ajo mouth to Punta Rasa. At local scale, the recent erosion of the 1-km long tip of the Punta Rasa Spit due to storm events (July 2009) clearly emerges by comparing Fig. 5d-e.

\section{Oceanographic and meteorological conditions}

Figure 6a shows the time series of the sea level recorded at Buenos Aires and Mar del Plata updated to 2010. The linear regression of the recorded data shows a trend of $1.62 \pm 0.05 \mathrm{~mm} \mathrm{yr}^{-1}$ and $1.72 \pm 0.10 \mathrm{~mm} \mathrm{yr}^{-1}$ for Buenos Aires and Mar del Plata, respectively.

Notice that these values are more specifically representative of the RSLR, i.e., the rise of the sea level relative to the adjacent land. Vertical land movements can contribute to RSLR with values comparable to the ocean fluctuations. Major components of VLM can be the post-glacial rebound, tectonics, and natural consolidation of sedimentary deposits as well as anthropogenic activities, such as fluid (groundwater or oil) withdrawals from the subsurface (Carbognin et al., 2011). Continuous GPS (CGPS) measurements at tide gauges can be used to correct the sea level trend for VLM (Brooks et al., 2007).

Although no VLM measurements are available in the Samborombón Bay, the CGPS stations at Buenos Aires, La Plata, and Mar del Plata, established in 2004, 1994 and 2002, respectively, are used to reliably estimate the VLM signals in the study area. The recorded VLM, 

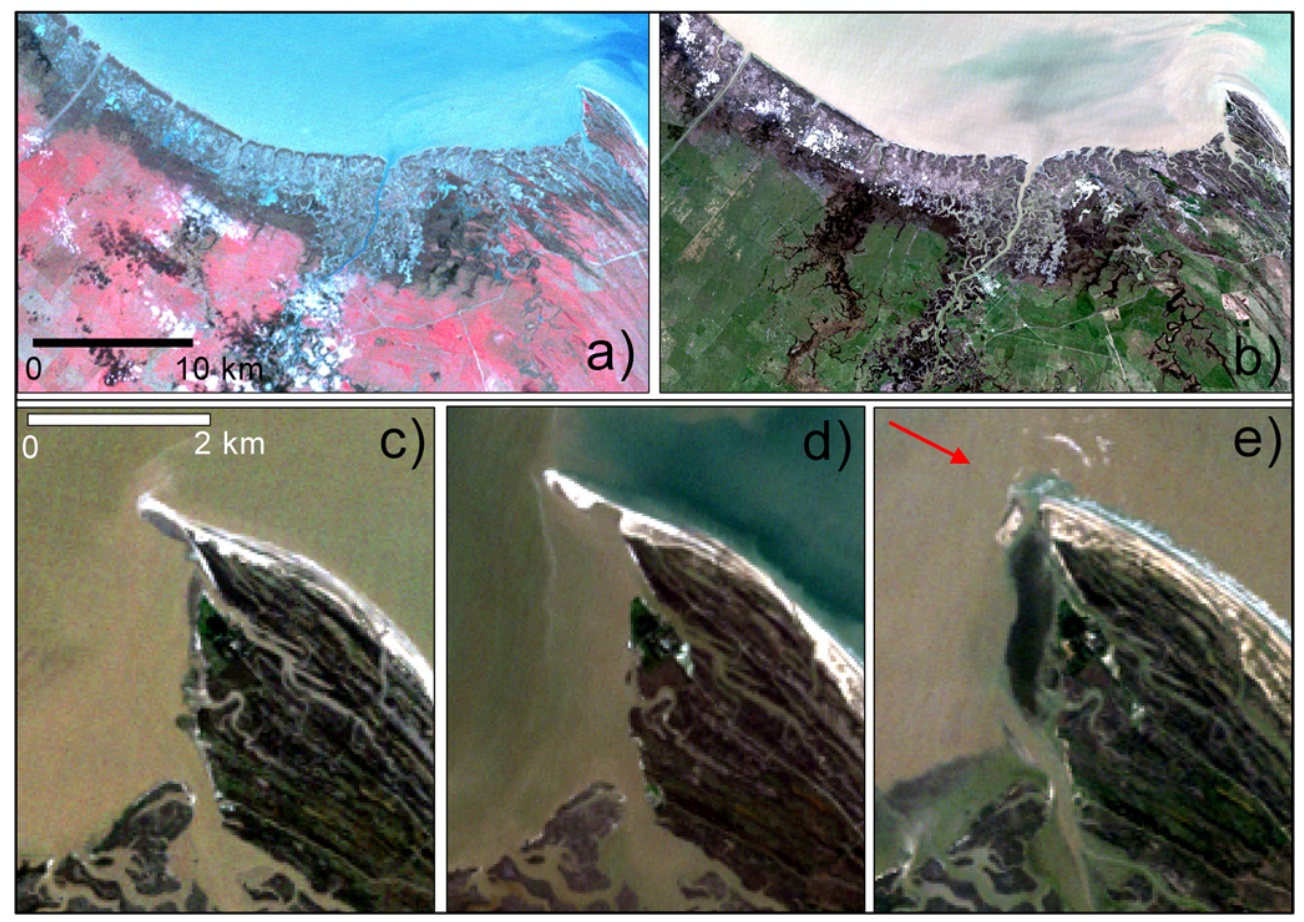

Fig. 5. Landsat images of the southern sector of the Samborombón coast acquired on (a) 20 September 1976 and (b) 1 October 2011. Acquisitions dated (c) 13 September 1987, (d) 11 September 2001, and (e) 25 September 2009 show the morphologic evolution of Punta Rasa spit; the red arrow points out the erosion of the spit tip.

which is mainly caused by long-term processes, amounts to $2.5 \pm 1.1 \mathrm{~mm} \mathrm{yr}^{-1}$ in Buenos Aires, $1.4 \pm 0.4 \mathrm{~mm} \mathrm{yr}^{-1}$ in La Plata, and $3.1 \pm 1.1 \mathrm{~mm} \mathrm{yr}^{-1}$ in Mar del Plata (www.sonel.org). For the Samborombón Bay, which is located about $150 \mathrm{~km}$ to the east of La Plata, it is reasonable to assume a $1 \mathrm{~mm} \mathrm{yr}^{-1}$ VLM. Although quite uncertain, this value is comparable to the long-term movement that we derived from the shelly ridges layers dated about 4.2-4.8 kyr BP (Fucks et al., 2010) and presently elevated 4$5 \mathrm{~m}$ a.s.l. The reconstruction of the most likely RSLR behavior at Samborombón Bay can be obtained by removing the average VLM recorded at Buenos Aires from the corresponding RSLR to obtain the absolute eustatic rate $(1.6+2.5=$ $4.1 \mathrm{~mm} \mathrm{yr}^{-1}$ ). Then the VLM estimated in the bay is added yielding an average $\sim 3 \mathrm{~mm} \mathrm{yr}^{-1}$ RSLR. The reconstructed time series obtained by this procedure are represented in Fig. 6b.

Concerning the meteo-climatic conditions, Samborombón Bay is normally affected by extratropical positive storm surges lasting from several hours to two or three days. Changes in the estuary water level are due to the cooscillating tide forced by the global tide along the shelf break. However, because of the shallowness and increasing width of the estuary, water level variations are strongly influenced by storm surges. Strong SE-SSE winds, which can occasionally reach $75-88 \mathrm{~km} \mathrm{~h}^{-1}$ at the Rio de la Plata outlet, push the estuary waters upriver, thus hindering drainage into the Atlantic. During the development of these episodes, locally known as "sudestadas" (southeasterlies), water can rise more than $3 \mathrm{~m}$, thus penetrating several kilometers inland and severely impacting the estuary shores. A dramatic example of a catastrophic "sudestada" in Buenos Aires and its surroundings occurred on 15 April 1940. The maximum tidal height predicted for that day was $1.20 \mathrm{~m}$ above datum, but the observed level was $4.44 \mathrm{~m}$ above datum, the surge being $3.24 \mathrm{~m}$. This is the maximum water level recorded since the beginning of tide measurements in 1905 . However, the highest positive surge occurred on 12 November 1989, peaking $3.48 \mathrm{~m}$. A return period of about $265 \mathrm{yr}$ was calculated for the maximum water level reached in Buenos Aires $(4.44 \mathrm{~m}$ over datum; D'Onofrio et al., 1999). An example of the difference between the observed level and the predicted tide during two extreme storms occurred in 1984 and 2009 is shown in Fig. 7.

By processing the hourly water levels from the Buenos Aires tide-gauge station, D'Onofrio et al. (2008) detected a statistically significant increase in the frequency and duration of positive surges over the three decades between 1974 and 2003. These authors also observed that the decadal averages of maximum and minimum heights for positive surges display an increasing trend. Similar results were obtained by Fiore et al. (2009) for Mar del Plata. Moreover, the decadal average of mean duration of these meteorological events is also increased during the three decades between 1976 and 

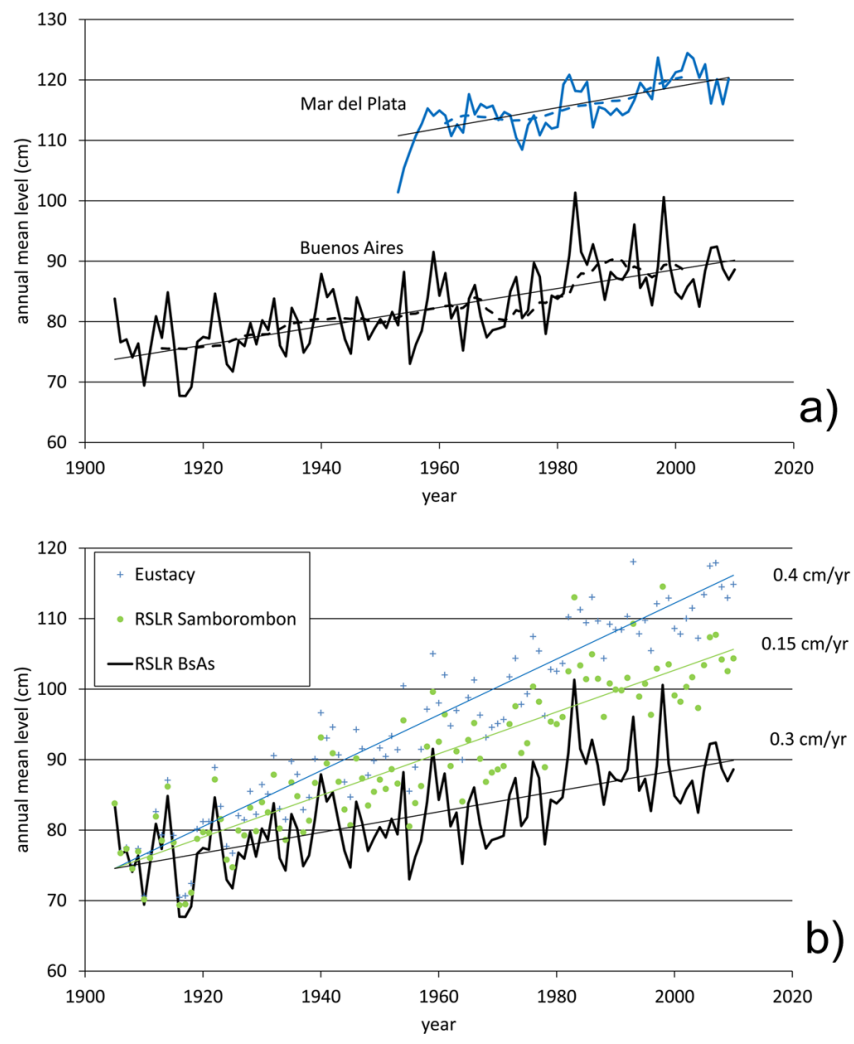

Fig. 6. (a) Time series of the MSL at Buenos Aires and Mar del Plata updated to 2010. (b) Time series of the RSLR at Buenos Aires, eustasy (i.e., the RSLR corrected of the VLM recorded by the GPS in Buenos Aires) and reconstructed RSLR (i.e., the eustacy plus the VLM) in the Samborombón Bay.

2005. A possible explanation of the changes in frequency, height, and duration of positive storm surges at Buenos Aires and Mar del Plata would seem to lie in the occurred RSLR. However, some evidences suggest a southward shift of the South Atlantic high during the last decades of the twentieth century (Camilloni, 2005), as well as a southward shift of the regional atmospheric circulation over the southeastern portion of South America (Barros et al., 2000). It is therefore possible that changes in the wind regime over the southwest Atlantic could drive to an increasing tendency of the positive storm surges characteristics as much as (or even more than) RSLR does.

An estimate of the potential impacts of RSLR on the hydro-morphologic setting of the Samborombón coastal plain is obtained by simple simulations developed using plausible RSLS projections at the end of the 21st century. Although Samborombón Bay is located within the Rio de la Plata estuary, it is assumed that the long-term behavior of the water level in the estuary will follow those in the open ocean as suggested by comparing the records in Buenos Aires and Mar del Plata. To taking into account the uncertainty affecting the expected rise, two RSLR scenarios are developed:
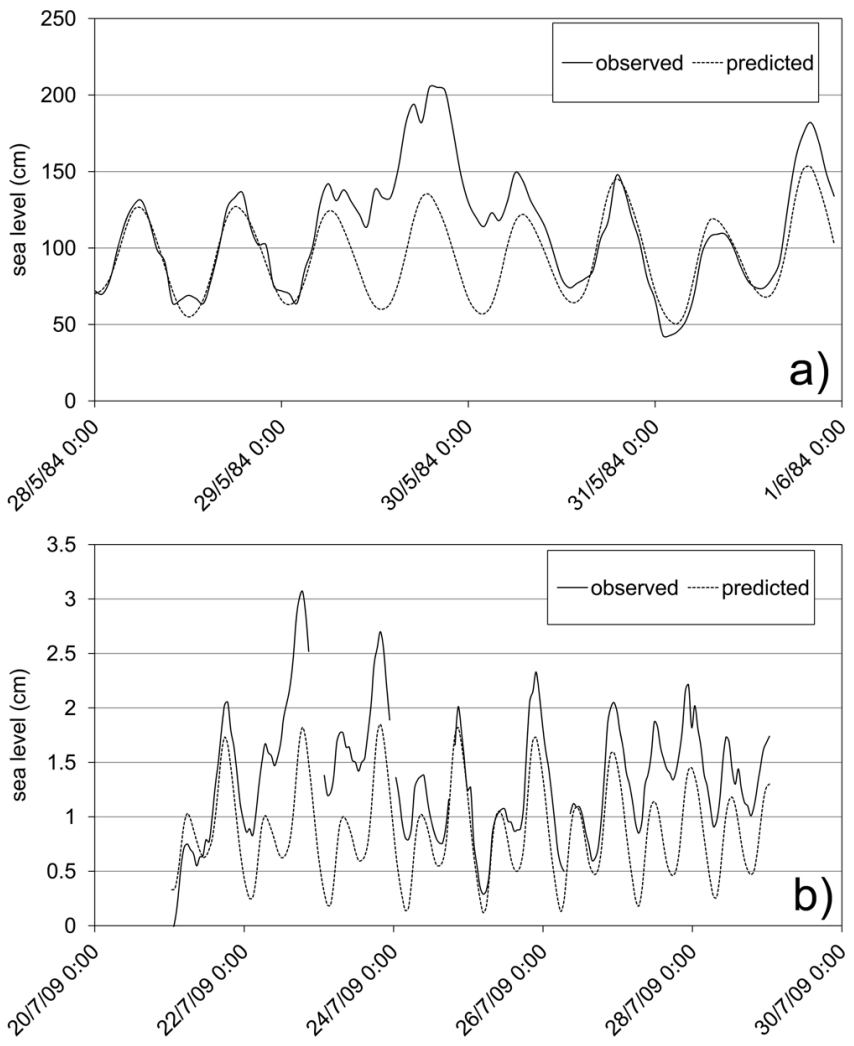

Fig. 7. An example of the difference between observed and the predicted tide levels during two extreme storm events recorded in Buenos Aires.

- $S_{1}$ : it is supposed that the $3 \mathrm{~mm} \mathrm{yr}^{-1}$ RSLR reconstructed on the Samborombón Bay coast for the past century will continue over the next $90 \mathrm{yr}$;

- $S_{2}$ : the second case is based on the $59-\mathrm{cm}$ eustatic rise corresponding to the upper limit of the F1FI scenario predicted by the IPCC (IPCC, 2007) for the year 2100. Considering a constant $1 \mathrm{~mm} \mathrm{yr}^{-1} \mathrm{VLM}$, as previously estimated for the study area, yielding a $9 \mathrm{~cm}$ uplift in 2100 , the expected RLSR at the end of the century will amount to $50 \mathrm{~cm}$.

Moreover, since the hydrologic setting of the coastal plain is strictly linked to tide conditions, the maximum marine flooding during high astronomical tides is investigated. According to sea level records at Buenos Aires, the average high tide amounts to $1.26 \mathrm{~m}$ above the Argentinean sea reference. As the difference between this latter and the Argentinean topographical reference plano de reduccion is $0.56 \mathrm{~m}$, the average high tide relative to the present DEM is equal to $0.70 \mathrm{~m}$. Hence, at the end of the 21st century, we consider a sea level $97 \mathrm{~cm}$ and $120 \mathrm{~cm}$ higher than the present value for the scenario $S_{1}$ and $S_{2}$, respectively. 


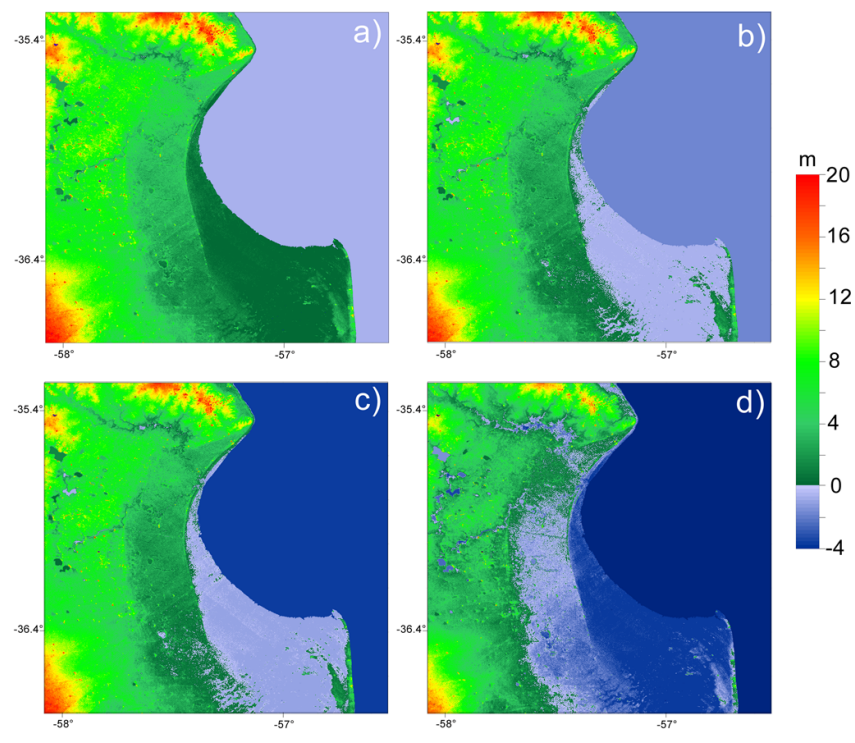

Fig. 8. (a) Digital Elevation Model of Samborombón Bay obtained by processing SRTM data. Flooded coastland expected in 2100 during a mean high tide level of $70 \mathrm{~cm}$ with (b) scenario $S_{1}$ and (c) scenario $S_{2}$, i.e., respectively $97 \mathrm{~cm}$ and $120 \mathrm{~cm}$ sea level higher than the present value. (d) Coastal flooding due to an extreme surge of $3.5 \mathrm{~m}$ sea level combined with $50 \mathrm{~cm}$ of $\operatorname{RSLR}\left(\mathrm{S}_{2}\right)$.

\section{Expected hydro-morphologic setting in $\mathbf{2 1 0 0}$}

The morphologic setting of the Samborombón coastal plain expected at the end of the 21 st century is obtained by combining the DEM of the study area (Fig. 8a) with the RSLR scenarios. The simulation results are shown in Fig. $8 \mathrm{~b}$ and c. The maps provide the flooding extent $\left(\sim 3000 \mathrm{~km}^{2}\right)$ that could be experienced during high tides in the worst condition, i.e., assuming that the sea reaches the whole area whose ground surface is below sea level during high tide irrespective of the distance from the coastline.

Although the extent of the flooded areas detected with the two scenarios does not differ significantly, the larger eustatic rise in the $S_{2}$ scenario could have a more severe impact on the morphologic setting of the bay. In fact, the previous analysis of satellite acquisitions showed that the RSLR experienced over the last decades did not cause significant changes. Thus, we can reasonably assume that sedimentation and $S_{1}$ RSLR rates will almost equilibrate. Higher RSLR values, such as that characterizing the $S_{2}$ scenario, probably will not allow the further aggradations of salt marshes, and consequently the morphologic setting of the bay is expected to change permanently.

\subsection{Northern sector}

The northern sector of Samborombón Bay will be the area less affected by RSLR because of its topographical elevation and the presence of narrow marshlands. The absence of surface watercourses will preclude the estuary water propagation into the mainland.

Freshwater lenses will be only partially reduced by RSLR because of their altitudes usually exceeding $5 \mathrm{~m}$ a.s.l. (Fig. 9a). Only locally, shell deposits less than $2.5 \mathrm{~m}$ high will lose in some degree their capability to store fresh water. Excavations of shelly sands will be flooded by the groundwater level rise (Fig. 9b). The groundwater salinity is expected to increase in all the environments influenced by tides because the estuary water will be more saline than today.

\subsection{Central sector}

The central sector of Samborombón Bay will be seriously affected by the RSLR because of its hydro-morphologic setting. Here, the salt marshes are wider than the northward and the depth to groundwater table is less than $1 \mathrm{~m}$ (Fig. 9c). Furthermore, because the elevation of the plain around the Salado and Samborombón Rivers is nearly at the mean sea level, severe flooding is expected during the wet seasons. During high tides the estuary waters will flood up from 10 to $20 \mathrm{~km}$ inland, reaching the high plateau located west of the coastal plain. The lowlands will be permanently flooded and most of the inner coastland areas will probably lie below the sea level for most of the time forming swamps and marshlands (Fig. 9d).

The rise in sea level is expected to change the chemical properties of surface water bodies, which will be affected by higher salinity waters both from the estuary and the brackish groundwater in the continental plain. The reserves of fresh water located in the shell ridges are expected to be drastically reduced due to the low altitude of these morphological features in the central sector of the bay (Fig. 9d).

\subsection{Southern sector}

Due to its very low elevation (Fig. 9e), the southern coastal plain will be permanently flooded, irrespective of the RSLR scenario. Flooding will enter inland for more than $40 \mathrm{~km}$ from the present coastline and the canals will be seriously encroached by tidal flow. Under these conditions, the loss of land due to flooding will reach an area of $2300 \mathrm{~km}^{2}$, with a general strong salinization of the whole environment. Freshwater resources contained in the sand deposits will completely disappear due to their elevation, presently about 1.5 m a.s.l. (Fig. 9f).

\section{Flooded areas during extreme storm surges}

The analyses performed above are focused on the almost permanent regression of the coastline. Here, the extent of the coastland, which is expected to be temporarily inundated for extreme levels in the estuary, is addressed. To this aim, the expected $S_{2}$ scenario of RSLR $(50 \mathrm{~cm}$ at the end of the 21 st century) is combined with a $3.5 \mathrm{~m}$ high southeasterlies, 


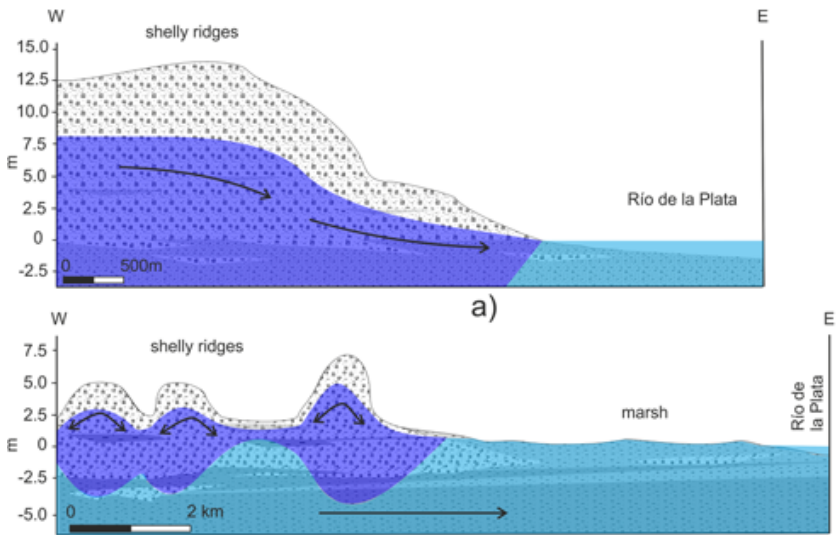

c)

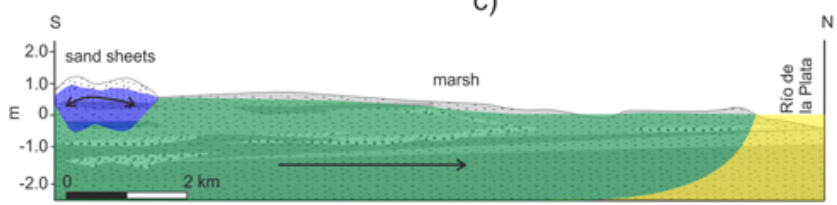

e)

WATER

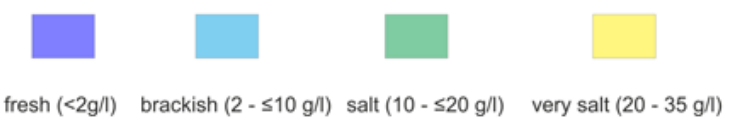

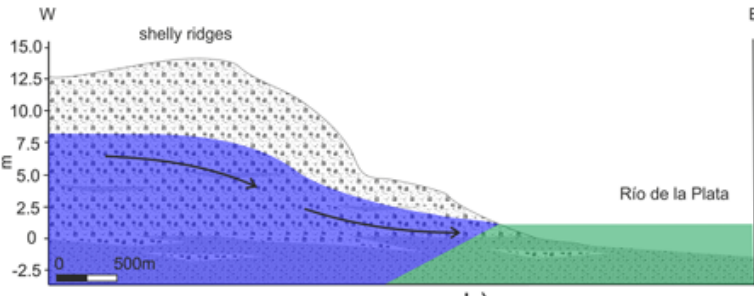

b)

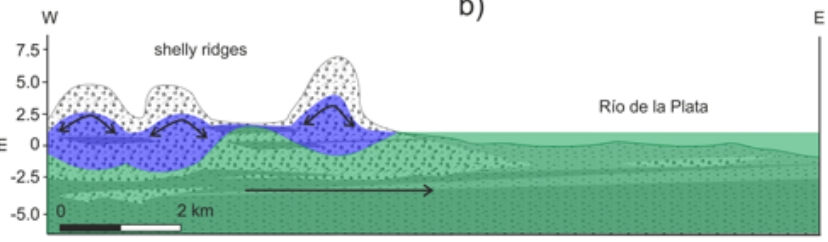

d)

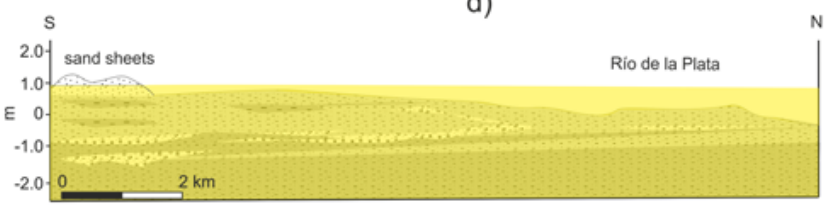

f)
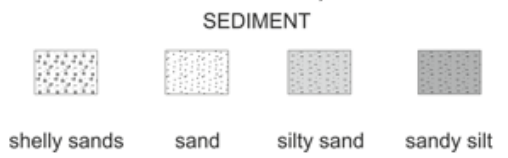

Fig. 9. Hydrogeologic conceptual models along representative cross sections of the Samborombón Bay. Present setting: (a) northern sector, (c) central sector, and (e) southern sector. Expected changes induced by $\sim 1 \mathrm{~m}$ RSLR: (b) northern sector, (d) central sector, and (f) southern sector.

which is characterized by a 5-yr return period in Buenos Aires (D'Onofrio et al., 1999). Numerical simulations have shown that during storm surges the sea levels increase from Punta Piedras toward Punta Rasa due to the water depth and width reduction of the bay (Ré, 2005). Although the computed sea level variations are significant (up to $50 \%$ ), a homogeneous RSLR of $4 \mathrm{~m}$ in the whole Samborombón Bay is safely considered in this analysis. As above, the SRTM DEM is used as reference for the coastland elevation.

Figure 8d shows the result of the simulation taking into account a sea level $4 \mathrm{~m}$ higher than the present. As such meteo-marine events are characterized by a significant duration, the estuary waters are expected to flood $\sim 5300 \mathrm{~km}^{2}$ of the coastal plain, especially to the south $\left(\sim 4000 \mathrm{~km}^{2}\right)$. The results indicate that several small villages will probably have to be evacuated. The risk of flooding will also likely increase in areas not directly on the coast, but exposed to rising water levels along rivers and lakes.

\section{Conclusions}

As a large portion of the coastland of the Samborombón Bay, a Ramsar conservation site, lies at an elevation which does not exceed $1 \mathrm{~m}$ a.s.l., permanent lowland inundation and retreat of the shoreline during next century are highly probable. On the basis of the prediction of projected mean sea level rise combined with high tides and extreme storm surges, maps showing the portion of the Samborombón coastal area that is likely to be flooded in the years to come, and the possible coastline retreat, are generated. Permanent coastland flooding will induce a significant change of the hydromorphologic setting and 2-3-day-long extreme events will seriously threaten buildings and human activities.

Maps of potentially flooded lowlands are generated by comparing the expected RSLR with a DEM of the study area. The simulated scenarios investigate the effects of sea levels $97 \mathrm{~cm}, 120 \mathrm{~cm}$ and $400 \mathrm{~cm}$ higher than the present value. The results clearly show that tidal flats and marshes may be permanently flooded by the sea and, as a consequence, ecohydrological characteristics of the coastal wetland will be greatly affected. The extent of the likely affected areas will significantly vary according to their location along the bay. In the northern sector, a narrow band of a few hundred meters will be affected by the estuary water. In the central zone, a larger lowland area from 600 to $1300 \mathrm{~km}^{2}$ (according with the various scenarios) will be flooded by the estuary water, with seawater encroachment in rivers and canals amounting to more than $50 \mathrm{~km}$ from the present mouth. The worst situation is expected to the south, where the RSLR effect during storm surges will threaten an area up to $50 \mathrm{~km}$ wide and exceeding $4000 \mathrm{~km}^{2}$. 
Consequently, a new groundwater - estuarine waters - surface waters balance will occur, with a rise of groundwater levels in floodplain and an increase of flooding risk in regions devoted to livestock production. In this situation a serious decrease of the volume of freshwater reserves is expected because of saltwater encroachment. If this reduction is negligible in the northern sector, RSLR will practically contaminate the whole freshwater lens located in the sandy layers and shell ridges to the south. Moreover, the excavations produced by the quarrying of shelly sand layers will be totally or partially flooded by the rising of groundwater level and the estuary water discharge. The evolution of the hydromorphologic setting described above can be extrapolated to other coastal plains with similar geological and geomorphologic conditions, relatively low human pressures, and the lack of artificial coastal protections.

Acknowledgements. This work was developed under the Scientific Cooperation Agreement between the CONICET (Argentina) CNR (Italy), Program 2011-2012, Project "Fresh- saltwaters in high-value coastlands: from the hydrogeophysical/geochemical characterization of the present interactions to the modeling quantification of the expected effects of climate changes". Satellite images are obtained from the US Geological Survey - Earth Resources Observation and Science (EROS) Center. SRTM data V4, the USGS/NASA, are from the International Centre for Tropical Agriculture (CIAT); GPS and tide gauge time series from SONEL and Argentine Hydrographic Service (Servicio de Hidrografia Naval, SHN), respectively. The constructive comments of the anonymous reviewers are also gratefully acknowledged for significantly helping to improve the original manuscript.

Edited by: M.-C. Llasat

Reviewed by: two anonymous referees

\section{References}

Acha, M., Mianzan, H., Guerrero, R., Carreto, J., Giberto, D., Montoya, N., and Carignan, M.: An overview of physical and ecological processes in the Rio de la Plata Estuary, Cont. Shelf Res., 28, 1579-1588, 2008.

Barros, V. R., Castañeda, M. E., and Doyle, M. E.: Recent precipitation trends in southern South America east of the Andes: an indication of climatic variability, in: Southern Hemisphere Paleoand Neoclimates, edited by: Smolka, P. P. and Volkheimer, W., Springer, Berlin, 187-206, 2000.

Brooks, B. A., Merrifield, M. A., Foster, J., Werner, C. L., Gomez, F., Bevis M., and Gill, S.: Space geodetic determination of spatial variability in relative sea level change, Los Angeles basin, Geophys. Res. Lett., 34, L01611, doi:10.1029/2006GL028171, 2007.

Camilloni, I.: Tendencias climáticas, in: El Cambio Climático en el Río de la Plata, edited by: Barros, V., Menéndez, A., and Nagy, G., CIMA-CONICET, Buenos Aires, 2, 13-19, 2005.

Carbognin, L., Teatini, P., Tosi, L., Strozzi, T., and Tomasin, A.: Present relative sea level rise in the Northern Adriatic coastal area, in: Marine Research at CNR, Coastal and Marine Spatial Planning, edited by: Brugnoli, E., Cavarretta, G., Mazzola, S., Trincardi, F., Ravaioli, M., and Santoleri, R., Consiglio Nazionale delle Ricerche, Dipartimento Terra e Ambiente, 1147-1162, ISSN 2239-5172, available at: http://www.dta.cnr.it/ content/view/7204/304/lang, en, 2011.

Carol, E., Kruse, E., and Pousa, J.: Environmental hydrogeology of the southern sector of the Samborombón Bay wetland, Argentina, Environ. Geol., 54, 95-102, 2008.

Carol, E., Kruse, E., and Mas-Pla, J.: Hydrochemical and isotopical evidence of ground water salinization processes on the coastal plain of Samborombón Bay, Argentina, J. Hydrol., 365, 335-345, 2009.

Carol, E., Kruse, E., and Roig, A.: Groundwater travel time in the freshwater lenses of Samborombón Bay, Argentina, Hydrol. Sci. J., 55, 754-762, 2010.

Cavallotto, J. L., Violante, R. A., and Parker, G.: Sea-level fluctuations during the last 8600 years in the de la Plata river (Argentina), Quaternary Int., 114, 155-165E, 2004.

Conzonno, V., Miretzky, P., and Fernandez Cirelli, A.: The impact of man-made hydrology on the lower stream bed of the Salado River drainage basin (Argentina), Environ. Geol., 40, 968-972, 2001.

D’Onofrio E. E., Fiore, M. E., and Romero, S. I.: Return periods of extreme water levels estimated for some vulnerable areas of Buenos Aires, Cont. Shelf Res., 19, 1681-1693, 1999.

D'Onofrio, E. E., Fiore, M., and Pousa, J.: Changes in the regime of storm surges at Buenos Aires, Argentina, J. Coast. Res., 24, 260-265, 2008.

Diez, P. G., Perillo, G. M. E., and Piccolo, C. M.; Vulnerability to Sea-Level Rise on the Coast of the Buenos Aires Province, J. Coast. Res., 23, 119-126, 2007.

Eaton, A. D., Clesceri, L. S., Greenberg, A. E., and Franson, M. A. H.: Standard Methods for the Examination of Water and Wastewater, American Public Health Association, Washington, DC, 1998.

Fiore, M. E, D’Onofrio, E. E., Pousa, J. L., Schnack, E. J., and Bertola, G. R.: Storm surges and coastal impacts at Mar del Plata, Argentina, Cont. Shelf Res., 29, 1643-1649, 2009.

Fucks, E. E., Schnack, E. J., and Aguirre, M. L.: Nuevo ordenamiento estratigráfico de las secuencias marinas del sector continental de la Bahía Samborombón, provincia de Buenos Aires, Rev. Asoc. Geol. Argent., 67, 27-39, 2010.

Gornitz, V. M., Beaty, T. W., and Daniels, R. C.: A coastal hazards database for the US West Coast, ORNL/CDIAC-81, NDP043C: Oak Ridge National Laboratory, Oak Ridge, Tennessee, US, doi:10.3334/CDIAC/ssr.ndp043c, December, 1997.

Intergovernmental Panel on Climate Change (IPCC): The Physical Science Basis, Contribution of Working Group I to the Fourth Assessment Report of the Intergovernmental Panel on Climate Change, edited by: Solomon, S., Qin, D., Manning, M., Chen, Z., Marquis, M., Averyt, K. B., Tignor M., and Miller, H. L., Cambridge Univ. Press, Cambridge, 966 pp., 2007.

Jarvis, A., Reuter, H. I., Nelson, A., and Guevara, E.: Hole-filled seamless SRTM data V4, International Centre for Tropical Agriculture (CIAT), available at: http://srtm.csi.cgiar.org (last access: December 2012), 2008.

Lamaro, A., Torrusio, S. E., Ulibarrena, J., Mugni, H., and Bonetto, C.: Mapping of Coastal Changes Applying Maps, Satellite Im- 
ages and GIS in Samborombón Bay, Argentina, Int. J. Ecol. Dev., 12, W09, ISSN: 0972-9984, 2009.

Nicholls, R. and Cazenave, A.: Sea-level rise and its impact on coastal zones, Science, 328, 1517-1520, 2010.

Pousa, J., Tosi, L., Kruse, E., Guaraglia, D., Bonardi, M., Mazzoldi, A., Rizzetto, F., and Schnack, E.: Coastal processes and environmental hazards: The Buenos Aires (Argentina) and Venetian (Italy) littorals, Environ. Geol., 51, 1307-1316, 2007.

Ré, M.: Impacto del cambio climatico global en las costas del Rio de La Plata, Msc Thesis, Facultad de Ciencias Exactas y Naturales, Universidad de Buenos Aires, October, 2005.

Reuter, H. I., Nelson, A., and Jarvis, A.: An evaluation of void filling interpolation methods for SRTM data, Int. J. Geogr. Inf. Sci., 21, 983-1008, 2007.

Strauss, B. H., Ziemlinski, R., Weiss, J. L., and Overpeck, J. T.: Tidally adjusted estimates of topographic vulnerability to sea level rise and flooding for the contiguous United States, Environ. Res. Lett., 7, 014033, doi:10.1088/1748-9326/7/1/014033, 2012.
Syvitski, J. P. M., Kettner, A. J., Hannon, M. T., Hutton, E. W. H., Overeem, I., Brakenridge, G. R., Day, J., Vörösmarty, C., Saito, Y., Giosan, L., and Nicholls, R. J.: Sinking deltas due to human activities, Nat. Geosci., 2, 681-689, 2009.

Teatini, P., Tosi, L., and Strozzi, T.: Quantitative evidence that compaction of Holocene sediments drives the present land subsidence of the Po Delta, Italy, J. Geophys. Res., 116, B08407, doi:10.1029/2010JB008122, 2011.

Violante, R. A. and Parker, G.: The post-last glacial maximum transgression in the de la Plata River and adjacent inner continental shelf, Argentina, Quaternary Int., 114, 167-181, 2004.

Violante, R., Parker, G., and Cavallotto, J.: Evolución de las llanuras costeras del este bonaerense entre la bahía de Samborombón y la laguna de Mar Chiquita durante el Holoceno, Rev. Asoc. Geol. Argent., 56, 51-66, 2001. 